\title{
Pemodelan Shopping Trips dan Analisis Faktor-Faktor yang Mempengaruhi Keputusan Pemilihan Suatu Mall sebagai Tempat Berbelanja (Studi Kasus pada Mall di Kawasan Sekitar Jakarta Utara)
}

\author{
Ita Handayani ${ }^{1}$, Ria Indrasari ${ }^{2}$, Siti Sofiatun ${ }^{3}$ \\ ${ }^{1}$ Universitas Pamulang, \\ ${ }^{2}$ STKIP Surya \\ ${ }^{3}$ MAN Insan Cendikia Serpong
}

\begin{abstract}
Abstrak
Jika kita melihat shopping trips yang dilakukan orang-orang yang tinggal di sebuah pemukiman di suatu daerah selama periode waktu tertentu, bagaimanakah kita mengembangkan sebuah model perilaku belanja yang cocok? Paper ini menyajikan pendekatan pemodelan untuk menggambarkan perilaku belanja di mall wilayah sekitar Jakarta Utara. Selain itu, faktor-faktor yang mungkin berpengaruh terhadap perilaku belanja tersebut juga dianalisis untuk melihat keakuratan dari pendekatan model yang dibuat. Tujuan dari studi ini adalah untuk mengetahui jumlah tarikan pengunjung perjalanan belanja ke suatu mall di Jakarta Utara. Data primer diperoleh dari hasil tanya jawab dengan penduduk di Jakarta Utara terkait trayek transportasi menuju mall, sedangkan data sekunder diperoleh dari hasil browsing internet berupa data variabel luas mall, luas retail floor, jumlah penduduk per kecamatan, jumlah toko, kapasitas parkir kendaraan, banyaknya alternatif transportasi, prosentase perkembangan distribusi pengeluaran, dan kategori mall. nKerangka pemodelan yang diusulkan adalah sebagai berikut. Pertama, model tarikan pengunjung dari sebuah kecamatan ke mall-mall yang ada di Jakarta Utara. Kedua, tarikan pengunjung dari sebuah kecamatan ke mall-mall yang ada di Jakarta Utara berdasarkan kategori mall dan kategori tingkat ekonomi penduduk di kecamatan tersebut. Kedua pendekatan model yang dibuat dapat dijadikan pertimbangan dalam pengambilan kebijakan bagi pemerintah kota terkait dalam melakukan pengembangan tata kota, baik dari sisi lalu lintas maupun pengaturan gerakan distribusi barang.
\end{abstract}

Kata kunci: shopping trips, simulasi model, daya tarik.

\section{Pendahuluan}

Shopping trips adalah komponen penting dari lalu lintas perkotaan, karena fenomena tersebut berkaitan dengan pergerakan orang dan kebutuhan hidup. Selain itu, pola perjalanan untuk belanja mengalami perubahan secara terus menerus dikarenakan perkembangan perkotaan dan kecenderungan perubahan skema distribusi baru ritel dan logistik. Di Jakarta khususnya, sebagai ibukota negara memang mengharuskan adanya kecukupan dalam segala hal, utamanya adalah pemenuhan kebutuhan hidup, baik berupa barang maupun jasa pelayanan. Pemenuhan kebutuhan tersebut ditopang dari ketersediaan tempat belanja yang menarik. Artinya, baik dari segi kenyamanan berbelanja, akses ke lokasi belanja, keragaman barang yang dijual, dan faktor-faktor lain yang menjadi pertimbangan seseorang dalam memutuskan pilihannya untuk berbelanja di suatu tempat. Salah satu tempat belanja yang menjadi fokus dalam membuat pendekatan pemodelan perilaku berbelanja adalah mall. Semakin diterimanya eksistensi mall di masyarakat, membuat banyak investor tertarik untuk menanamkan modalnya dalam bisnis tersebut. Apalagi di kota besar seperti Jakarta yang penduduknya terus bertambah. Banyak terdapat mall yang bersaing ketat untuk menjaring pengunjung, dari pertimbangan lokasi mall, fasilitas mall, dan lain-lain. Untuk bisa bersaing atau menjaring pengunjung mall atau pembeli sebanyak mungkin, sebuah mall harus dapat memberikan kepuasan kepada pengunjung. Salah satu indikator ketercapaian kepuasan pengunjung secara umum adalah bila pengunjung merasa semua kebutuhannya dapat diperoleh secara mudah dengan pelayanan yang baik. Namun, kendala bagi mall adalah mencari titik temu antara barangbarang atau produk dan pelayanan yang ditawarkan oleh mall dengan kebutuhan yang diperlukan oleh pengunjung mall. Upaya membuat pengunjung tertarik untuk datang ke suatu mall lalu melakukan transaksi bukanlah hal yang mudah mengingat bahwa pengunjung datang ke pusat perbelanjaan berupa mall mempunyai tujuan dan motif yang berbeda mulai dari sekedar melihat-lihat, rekreasi, 
atau khusus untuk berbelanja kebutuhan mereka. Penyusunan strategi yang tepat dan efektif dengan memperhatikan beragam faktor pendukung maupun penghambat serta potensi yang dimiliki dan perlu dioptimalkan dengan tujuan membuat ketertarikan pengunjung mall perlu dibuat oleh pihak managemen perusahaan.

Kota Jakarta Utara merupakan salah satu daerah di wilayah Jakarta yang mengalami perkembangan cukup pesat, terutama di sektor pembangunan pusat perbelanjaan yang merupakan salah satu dampak maraknya penambahan jumlah perumahan yang ada di wilayah tersebut. Misalnya, di wilayah kecamatan Kelapa Gading telah berdiri Mall of Indonesia, Mall Kelapa Gading, I, II, III, dan V. Pusat perbelanjaan, sebagai salah satu tata guna lahan, mempunyai intensitas yang cukup tinggi dalam menarik pergerakan, mengingat pola hidup masyarakat yang tidak bisa terlepas dari gaya hidup berbelanja untuk memenuhi kebutuhannya. Keberadaan pusat perbelanjaan sebagai salah satu fasilitas komersial selain pasar tradisional dan toko/warung tersebut dapat menimbulkan implikasi yang beragam terhadap arah pembangunan kota dan pergerakan penduduknya. Besarnya aktivitas pada pusat-pusat perbelanjaan tersebut telah meningkatkan kompleksitas pergerakan arus lalu lintas pada ruas jalan di sekitarnya, seperti terjadinya peningkatan volume lalu lintas, derajat kejenuhan, serta konflik lalu lintas menerus dan lokal (weaving). Merebaknya pusat perbelanjaan yang berada di Jakarta Utara saat ini menyebabkan permasalahan lalu lintas pada jaringan jalan di sekitarnya kian meningkat, sehingga pada tahap awal perlu dilakukan studi atau evaluasi untuk mengetahui besarnya tarikan perjalanan menuju pusat perbelanjaan di Jakarta Utara, khususnya mall.

\section{Metode Penelitian}

\subsection{Pengertian Pemodelan}

Secara bahasa matematika, pemodelan adalah suatu pemetaan dari suatu himpunan bagian dari dunia nyata sebagai domainnya kedalam suatu himpunan struktur sebagai kodomainnya, untuk mencapai tujuan dengan mereduksi kompleksitasnya.

Adapun tahapan kegiatan pemodelan ditampilkan seperti Gambar 1.

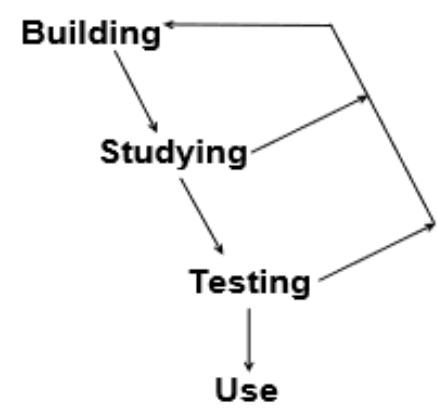

Gambar 1. Kegiatan Pemodelan

\subsection{Cara Penyajian Model}

Sebagaimana cara menyajikan fungsi/pemetaan, maka ada 4 (empat) cara untuk menyajikan suatu model, yaitu:

a) Dengan map

Jika kita perhatikan dengan seksama, maka peta jalan pada suatu daerah merupakan model dari daerah tersebut yang berbentuk map, photo kita merupakan model diri kita yang berbentuk gambar, gambar yang kita buat juga merupakan model dari objek yang kita gambar. Gambar di TV atau Film juga merupakan model yang berbentuk map. Banyak lagi model yang dapat ditemui di sekitar kita yang berupa map ini.

b) Dengan deskripsi verbal

Majalah atau koran yang dapat dipercaya kebenaran beritanya, merupakan model dari fenomena nyata yang dimodelkan dalam bentuk diskripsi verbal. Sedangkan berita yang tidak benar bukan merupakan model karena sebetulnya fenomena nyata sebagai domainnya yang dimodelkan sesungguhnya tidak ada. Kalau orang membuat suatu laporan baik lisan maupun tertulis, berarti orang tersebut sedang melakukan pemodelan yang berbentuk verbal deskripsi. Berita atau informasi yang dapat kita lihat dalam bentuk tulisan atau yang dapat didengar dari TV atau Radio merupakan model diskripsi verbal juga. Contoh lain dapat dicari dari sekeliling kita.

c) Dengan daftar ukuran

Seorang penjahit yang membuat daftar ukuran badan seseorang yang dibuat bajunya berarti dia sedang membuat model badan orang tersebut dalam bentuk daftar ukuran. Contoh lain, jika kita makan di restoran kemudian diberikan daftar harga menu yang disediakan, berarti kita sedang menghadapi model makanan dalam bentuk daftar ukuran harganya.

d) Dengan model matematika

Sejak kecil kita sudah diajari matematika, mulai dari bilangan nyata sampai dengan menggunakan banyak simbol sebagai abstraksi 
dari keadaan nyata. Proses abstraksi dengan menggunakan simbol-simbol inilah yang disebut sebagai pemodelan matematika.

\subsection{Perilaku Konsumen}

Menurut Basu Swastha (dalam Raharjani, 2005), perilaku konsumen dapat diartikan sebagai suatu kegiatan-kegiatan individu yang secara langsung terlibat dalam mendapatkan serta menggunakan barang-barang dan jasajasa, termasuk di dalturmya proses pengambilan keputusan pada persiapan dan penerapan kegiatan.

Banyak variabel yang mempengaruhi perilaku konsumen dan kecenderungannya untuk saling berinteraksi. Model perilaku konsumen dikembangkan sebagai usaha untuk memahami variabel-variabel dalam perilaku konsumen. Berikut ini akan dibahas sebuah model perilaku konsumen.

\begin{tabular}{|c|c|c|}
\hline Rangsangan dari luar & Kotak Hitam & Jawaban Pembeli \\
\hline $\begin{array}{l}\text { Pemasaran: Produk, } \\
\text { harga tempat, promosi }\end{array}$ & $\begin{array}{l}\text { Ciri pribadi: budaya, sosial } \\
\text { perorangan, psikologis. }\end{array}$ & $\begin{array}{l}\text { Pilihan produk, pilihan } \\
\text { Merk, pilihan penjual, }\end{array}$ \\
\hline $\begin{array}{l}\text { Lingkungan: Ekonomi, } \\
\text { teknologi, politik, budaya }\end{array}$ & $\begin{array}{l}\text { Proses PK: masalah, } \\
\text { mencari informasi, evaluasi, } \\
\text { keputusan perilaku beli }\end{array}$ & $\begin{array}{l}\text { panjangnya waktu pembeli } \\
\text { jumlah pembelian }\end{array}$ \\
\hline
\end{tabular}

Gambar. 2. Model Perilaku Pembeli

Perilaku konsumen akan menentukan proses pengambilan keputusan dalam pembelian mereka. Proses tersebut merupakan sebuah pendekatan penyelesaian masalah yang terdiri atas beberapa tahap. Seluruh proses tersebut tidak selalu dilakukan oleh konsumen dalam pembeliannya. Pada umumnya konsumen akan lebih mudah mengambil keputusan dalam pembelian ulang atau pembelian yang sifatnya terus menerus terhadap produk yang sama. Menurut Kotler (2003) dalam Raharjani (2005) tentang tahap-tahap dalam proses keputusan pembelian tersebut dapat digambarkan dalam sebuah model seperti Gambar 3.

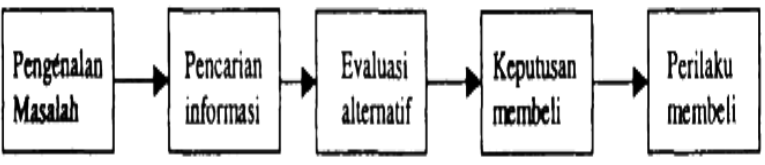

Gambar 3. Model 5 Tahap Proses Membeli

Keputusan pelanggan untuk mengunjungi mall tertentu merupakan pengambilan keputusan yang kompleks, karena boleh jadi pelanggan mengkaji terlebih dahulu bermacam-macam mallmall yang ada. Selain itu kunjungan tersebut juga bisa berdasarkan atas kesetiaan (loyalitas). Loyalitas terhadap mall tertentu adalah sifat menguntungkan bagi mall itu sendiri berdasarkan pengalaman mereka berkunjung ke mall tersebut. Ada beberapa faktor yang menyebabkan seorang pelanggan menjadi loyal mengunjungi suatu mall antara lain lokasi, luas mall, fasilitas, dan banyaknya toko yang menandai keragaman barang, serta alternatif transportasi menuju mall.

\subsection{Pengembangan Model}

Kajian terkait yang sudah pernah dilakukan antara lain:

a. Pemodelan Tarikan Perjalanan Menuju Pusat Perbelanjaan di Kabupaten Badung, Provinsi Bali, Putu Alit Suthanaya. Hasil analisis penggunaan moda pengunjung pusat perbelanjaan menunjukkan bahwa 58,43\% pengunjung menggunakan sepeda motor, $41,37 \%$ kendaraan ringan, $0,10 \%$ kendaraan berat, dan $0,10 \%$ kendaraan tidak bermotor. Dari hasil analisis multiple regresi diperoleh bahwa variabel bebas yang berpengaruh terhadap tarikan perjalanan pada kondisi jam puncak yaitu luas total lahan $\left(\mathrm{X}_{1}\right)$ dan luas areal parkir $\left(\mathrm{X}_{3}\right)$. Sedangkan untuk tarikan perjalanan satu hari, variabel yang berpengaruh hanya luas total lahan $\left(\mathrm{X}_{1}\right)$. Model tarikan perjalanan untuk satu jam puncak pada jam sibuk pagi/siang, sore/malam, dan untuk 1 hari pada hari kerja masing-masing: $\mathrm{Y}_{11}=105,747+0,005 \cdot \mathrm{X}_{1}\left(\mathrm{R}^{2}\right.$ $=0,967) ; Y_{12}=45,601+0,015 . X_{3}\left(R^{2}=0,984\right)$; $\mathrm{Y}_{13}=3405,73+0,187 . \mathrm{X}_{1}\left(\mathrm{R}^{2}=0,920\right)$.

b. Analisis Faktor-Faktor yang Mempengaruhi Keputusan Pemilihan Pasar Swalayan Sebagai Tempat Berbelanja (Studi Kasus pada Pasar Swalayan di Kawasan Seputar Simpang Lima Semarang), Jeni Raharjani. Setelah dianalisis dengan analisis regresi berganda diperoleh hasil bahwa ke-empat variabel tersebut mempengaruhi keputusan pemilihan pasar swalayan sebagai tempat berbelanja sebesar $57,5 \%$. Variabel yang paling berpengaruh adalah keragaman barang (0,374); lokasi $(0,323)$; fasilitas $(0,168)$ dan yang paling kecil pengaruhnya adalah variabel pelayanan $(0,097)$.

c. An Attractiveness-Based Model for Shopping Trips in Urban Areas, Jesus Gonzalez-Feliu, Jean-Louis Routhier, Charles Raux. Pendekatan pemodelan dibuat untuk menggambarkan perjalanan belanja mobil pribadi di titik logistik kota pandang. Selain itu, pemodelan juga digunakan untuk melihat hubungan gerakangerakan perjalanan belanja dengan distribusi barang perkotaan dalam rantai pasokan. Kerangka pemodelan yang diusulkan adalah dua macam. Pertama, model tarik yang memperkirakan jumlah perjalanan belanja 
mobil pribadi yang datang ke setiap bagian dari daerah perkotaan. Kedua, model daerah tangkapan yang menghubungkan destinasi perjalanan belanja dengan lokasi rumah tangga. Model ini dikalibrasi menggunakan data dari database kegiatan komersial dan survei perjalanan rumah tangga yang dibuat pada tahun 2006 di daerah perkotaan Lyon (Prancis). Hasil utama studi menyajikan berbagai simulasi serta beberapa contoh aplikasi dan proposal. Sebagian besar dari simulasi dipakai sebagai acuan dalam membuat perspektif kebijakan publik.

\section{Pembahasan}

Metode yang digunakan dalam memodelkan masalah shopping trips adalah dengan melihat berbagai literatur dari studi yang telah dilakukan. Perilaku model mengacu kepada aspek kuantitatif yaitu melihat banyaknya pengunjung mall dari berbagai kecamatan yang ada di sekitar Jakarta Utara. Pemilihan variabel pada pemodelan shopping trips yang pertama berdasarkan pertimbangan berikut:

a. Jumlah penduduk per kecamatan

Tujuan dari pemodelan pertama adalah menentukan jumlah tarikan pengunjung mall di wilayah Jakarta Utara. Oleh sebab itu, variabel jumlah penduduk sangat penting disertakan dalam model.

\section{b. Luas retail floor}

Luas keseluruhan toko yang ada di suatu mall juga bisa dimaknai bahwa area tersebut menjadi pusat aktivitas utama pengunjung mall.

c. Jarak mall ke kecamatan

Suatu hal yang sangat wajar jika pengunjung mall sangat mempertimbangkan jarak antara mall yang akan dikunjungi dengan lokasi mereka tinggal.

d. Banyak toko

Variabel ini disertakan dalam model disebabkan banyak toko bisa mencerminkan keragaman barang di suatu mall. Semakin lengkap barang yang dijual di mall maka kemungkinan besar seseorang akan tertarik untuk berbelanja di mall tersebut.

e. Banyaknya alternatif angkutan (baik transit atau direct) dari kecamatan ke mall

Logika sederhana yang dapat diterima oleh kebanyakan orang adalah semakin mudah akses perjalanan menuju suatu destinasi, maka destinasi tersebut adalah yang dipilih. Logika berpikir tersebut memjadikan variabel banyaknya alternatif angkutan disertakan ke dalam model.
Pemilihan variabel pada pemodelan shopping trips yang kedua berdasarkan pertimbangan berikut.

1) Jumlah penduduk per kecamatan berdasarkan tingkat ekonomi penduduk

Untuk melihat jumlah pengunjung mall dengan tingkat ekonomi tertentu di tiap kategori mall maka perlu dipertimbangkan jumlah penduduknya, baik yang kaya, sedang, maupun yang miskin.

2) Prosentase perkembangan distribusi pengeluaran

Variabel ini dipertimbangkan ke dalam model karena dianggap menunjukkan tingkat ekonomi (tinggi/kaya, menengah/sedang, dan rendah/miskin). Data diperoleh dari Badan Pusat Statistik 2010 untuk wilayah perkotaaan.

3) Kapasitas parkiran mobil

Untuk mengetahui banyaknya penduduk kaya yang berkunjung ke mall kategori mewah maka kapasitas parkiran mobil disertakan ke model. Pemikiran ini berdasarkan asumsi sederhana bahwa setiap orang kaya pasti mempunyai mobil.

4) Luas retail floor

Pertimbangan disertakannya variabel ini ke dalam model yang kedua sama dengan model pertama.

5) Jarak mall ke kecamatan

Pertimbangan disertakannya variabel ini ke dalam model yang kedua sama dengan model pertama.

6) Kapasitas motor

Untuk mengetahui banyaknya penduduk dengan tingkat ekonomi menengah yang berkunjung ke mall kategori mid-range maka kapasitas parkiran motor disertakan ke model. Pemikiran ini berdasarkan asumsi sederhana bahwa penduduk dengan tingkat ekonomi menengah pasti mempunyai motor.

7) Banyaknya alternatif angkutan (baik transit atau direct) dari kecamatan ke mall

Untuk mengetahui banyaknya penduduk dengan tingkat ekonomi rendah yang berkunjung ke mall kategori bawah maka akses angkutan umumlah yang dipikirkan dapat menjadi pertimbangan untuk dimasukkan ke dalam model.

\section{Simulasi Model}

Setelah data yang terkait dengan variabel yang telah diprediksi memberi pengaruh ke model, maka dilakukan tahap selanjutnya.

1) Model shopping trips pertama 
a. Langkah-langkah pemodelan

i. Menentukan proporsi pengunjung mall dari kecamatan- $i$ ke mall- $j$ :

$$
X_{i j}=\frac{A_{j} \cdot n_{j} \cdot t_{i j}}{d_{i j}^{3}}
$$

$A_{j}=$ luas retail floors di mall $-j$

$n_{j}=$ banyaknya toko di mall $-j$

$t_{i j}=$ transportasi umum dari kec - $\mathrm{i}$ ke ma mall $j$ $d_{i j}=$ jarak dari kecamatan $i$ ke

Data transportasi umum dibedakan menjadi dua macam akses, yaitu pertama, direct/langsung yang artinya penumpang hanya satu kali naik angkutan bis dari lokasi tempat tinggal menuju mall, kedua adalah transit yang artinya penumpang naik lebih dari satu macam angkutan menuju mall. Jika ada 3 pilihan direct, maka data angkutan diberi angka 3. Jika pengunjung transit 1 kali, maka diberi angka 0,5; 2 kali transit diberi angka 0,33 . Jika ada 2 rute direct dan 1 transit, maka diberi angka 2,5; dst.

ii. Menghitung peluang pengunjung mall dari kecamatan- $i$ ke mall-j:

$$
P_{i j}=\frac{X_{i j}}{\sum X_{i j}}
$$

$X_{i j}=$ proporsi pengunjung mall dari kec $-\mathrm{i}$ ke mall $-j$

$\sum X_{i j}=$ total proporsi pengunjung mall dari kec $-\mathrm{i}$ ke mall $-j$

iii. Banyak pengunjung mall- $j$ dari kecamatan- $i$ :

$$
\begin{aligned}
B_{i j}= & P_{i j} \times N_{i} \\
& P_{i j}=\text { peluang pengunjung mall dari kec }-\mathrm{i} \\
& N_{i}=\text { Jumlah penduduk di kecamatan } \mathrm{i}
\end{aligned}
$$

b. Analisis simulasi model pertama (rinciannya terlampir)

Tampilan grafik dari perhitungan pada pemodelan pertama sebagai berikut.

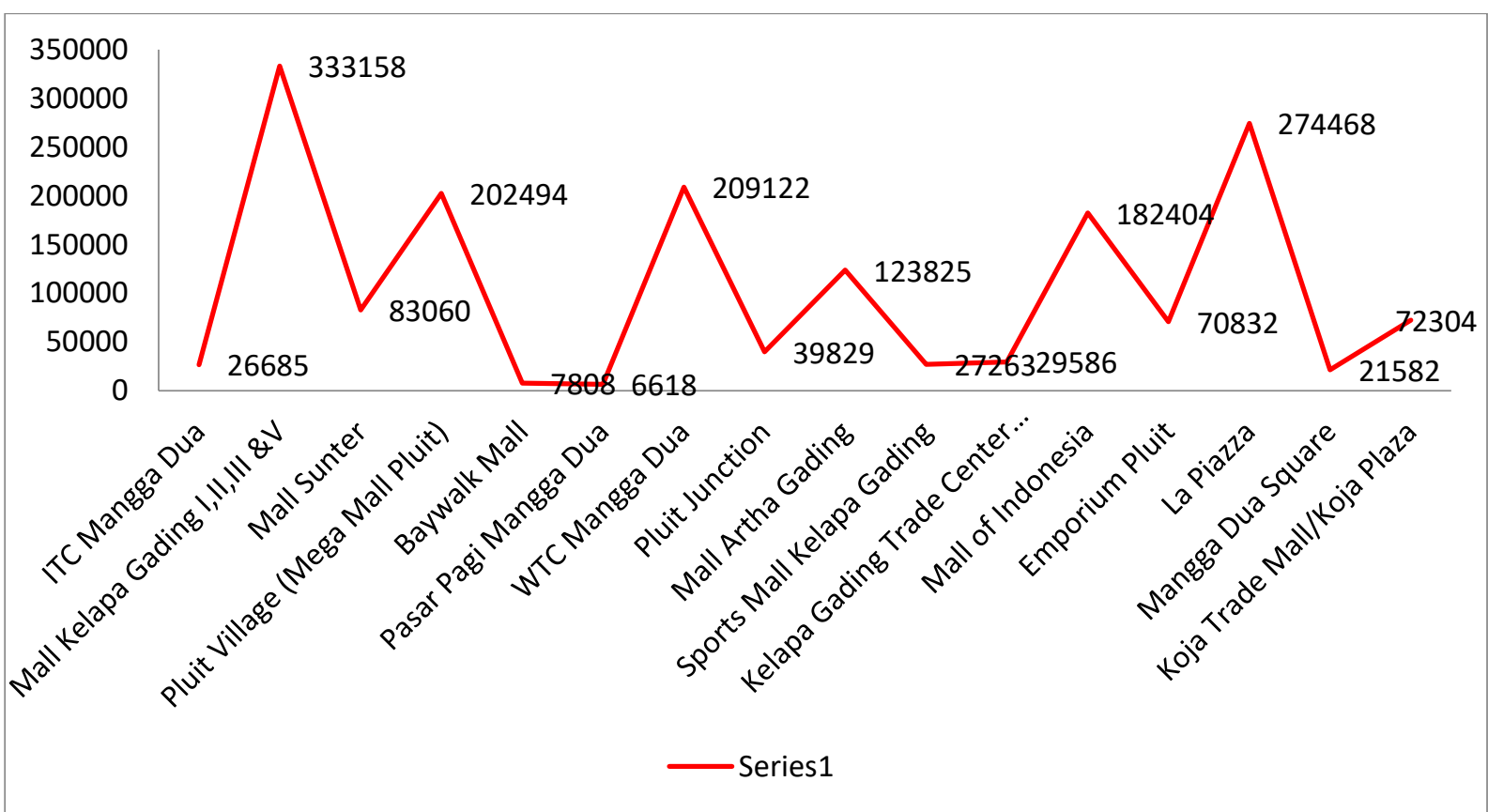

Gambar 4. Tampilan Grafik Jumlah Pengunjung Mall di Jakarta Utara

Berdasarkan grafik yang diperoleh datanya dari perhitungan di Excel, terlihat bahwa penduduk Jakarta Utara lebih memilih Mall Kelapa Gading I, II, III \& V untuk dikunjungi. Hal tersebut terlihat dari jumlah pengunjungnya yang mencapai 333158 orang, sedangkan mall yang paling sedikit pengunjungnya adalah Pasar Pagi Mangga Dua, yaitu 6618 orang.

2) Model shopping trips kedua

a. Langkah-langkah pemodelan

1) Menentukan proporsi pengunjung mall mewah (high-end) dari kecamatan- $i$ ke mall-j : 


$$
X_{i j}=\frac{A_{j} \cdot n_{j} \cdot c}{d_{i j}^{3}}
$$
mall-j

dengan $c$ adalah kapasitas mobil di

Perhitungan proporsi untuk mall mewah ada dua macam, yaitu X1 (proporsi yang memperhitungkan kapasitas mobil di mall sehingga rumus proporsinya adalah $X_{i j}=\frac{A_{j} \cdot n_{j} \cdot c}{d_{i j}{ }^{3}}$ ) dan $\mathrm{X} 2$ (proporsi tanpa memperhitungkan kapasitas mobil di mall sehingga rumus proporsinya adalah $X_{i j}=$ $\left.\frac{A_{j} \cdot n_{j}}{d_{i j}{ }^{2}}\right)$. Selanjutnya, dihitung peluang $\mathrm{X} 1$ $(\mathrm{P}(\mathrm{X} 1))$ dan peluang $\mathrm{X} 2(\mathrm{P}(\mathrm{X} 2))$. $\mathrm{P}(\mathrm{X} 1)$ dikalikan jumlah penduduk kaya $=$ jumlah penduduk dengan tingkat ekonomi tinggi yang berkunjung ke mall kategori mewah. $\mathrm{P}(\mathrm{X} 2)$ dikalikan jumlah penduduk menengah $=$ jumlah penduduk dengan tingkat ekonomi menengah yang berkunjung ke mall kategori mewah. P(X2) dikalikan jumlah penduduk miskin = jumlah penduduk dengan tingkat ekonomi rendah yang berkunjung ke mall kategori mewah. Perhitungan proporsi selanjutnya (untuk kategori mall menengah dan murah adalah analog seperti perhitungan proporsi mall mewah).

2) Menghitung proporsi pengunjung mall menengah (mid-range) dari kecamatan- $i$ ke mall-j:

$$
X_{i j}=\frac{A_{j} \cdot n_{j} \cdot b}{d_{i j}^{3}}
$$

dengan $b$ adalah kapasitas motor di mall-j

3) Menghitung proporsi pengunjung mall murah (cheap) dari kecamatan- $i$ ke mall- $j$ :

$$
X_{i j}=\frac{A_{j} \cdot n_{j} \cdot t_{i j}}{d_{i j}^{3}}
$$

b. Analisis simulasi model kedua (rinciannya terlampir)

Secara keseluruhan, hasil tampilan grafik dari model pertama sebagai berikut.

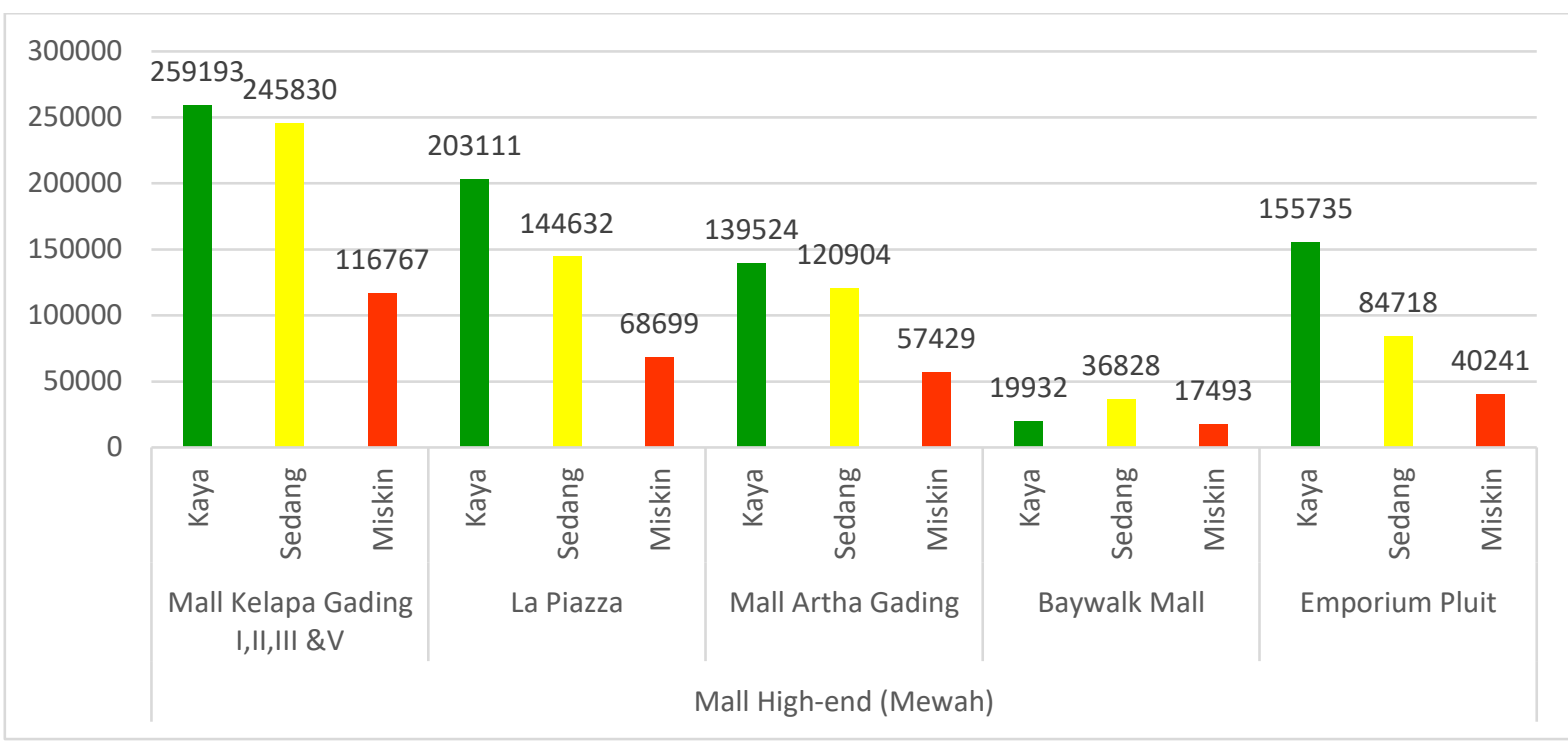

Gambar 5. Grafik Jumlah Pengunjung Mall Mewah

Mall kategori mewah yang paling banyak pengunjungnya adalah mall kelapa gading I, II, III dan $\mathrm{V}$ dan paling sedikit adalah baywalk mall. Pada kategori mall mewah pengunjung yang datang didominasi dari penduduk yang kaya.
Mall kategori menengah yang paling banyak pengunjungnya adalah Mall Of Indonesia dan paling sedikit adalah Sport Mall kelapa Gading. Pada kategori mall menengah pengunjung yang datang didominasi dari penduduk yang kaya dan sedang. 


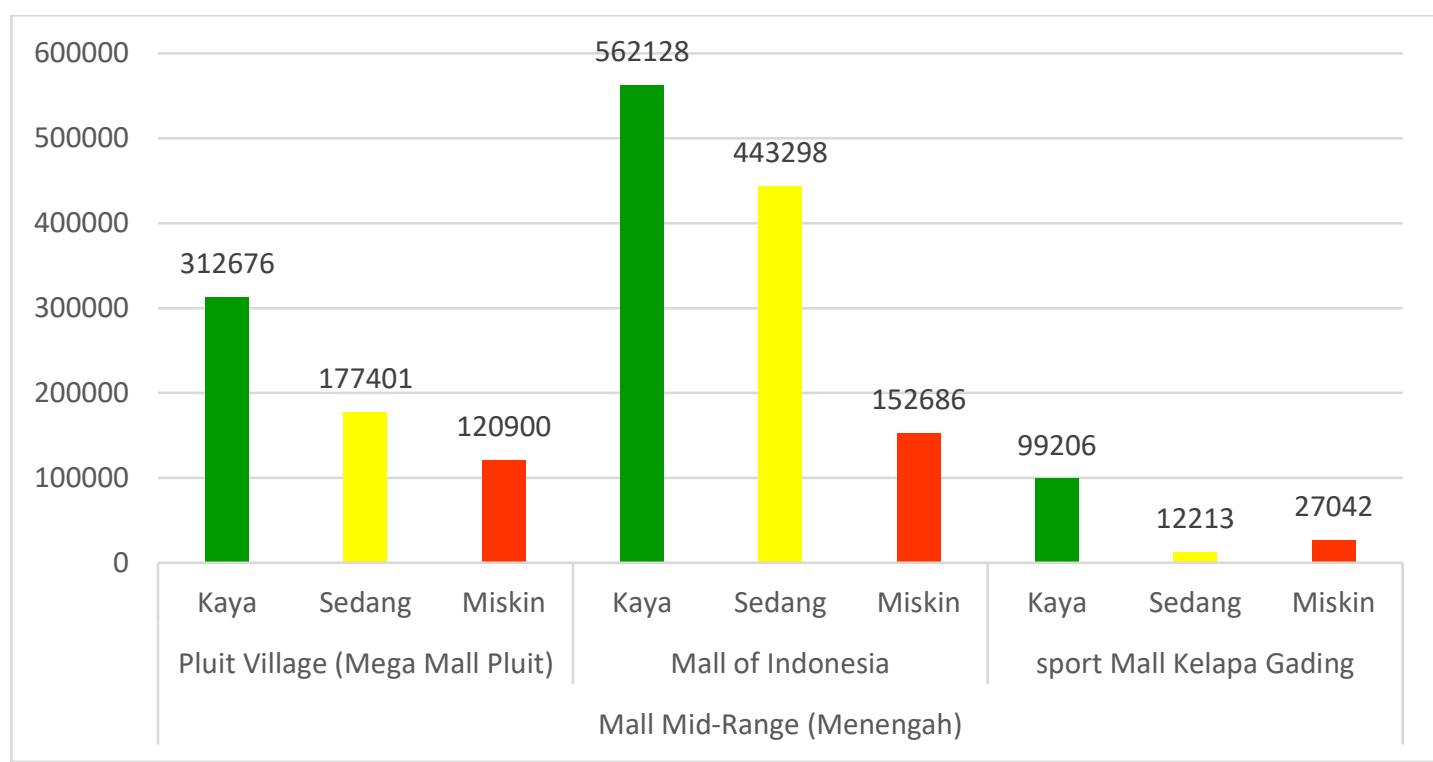

Gambar 6. Grafik Jumlah Pengunjung Mall Menengah

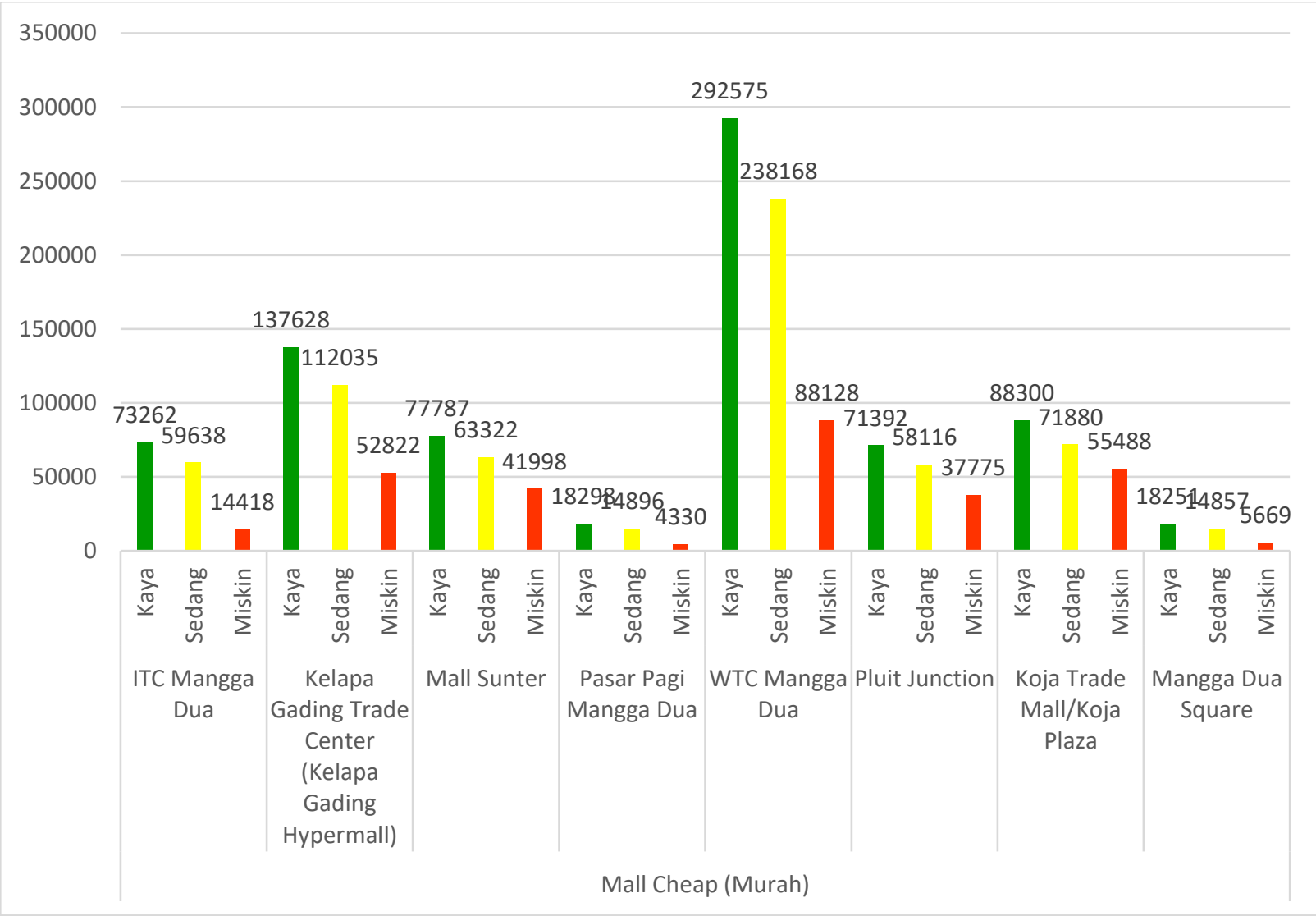

Gambar 7. Grafik Jumlah Pengunjung Mall Cheap

Pengunjung dengan tingkat ekonomi kaya lebih memilih WTC Mangga Dua, sedangkan Pasar Pagi Mangga Dua paling sedikit dikunjungi oleh penduduk dengan tingkat ekonomi miskin.

\section{Kesimpulan}

Hal-hal yang dapat disimpulkan dari studi ini sebagai berikut.
1. Faktor yang berpengaruh besar terhadap pemilihan suatu mall adalah jumlah penduduk. Hal tersebut bisa terlihat dari model yang dibuat. (peluang dikali jumlah penduduk).

2. Faktor berikutnya yang juga berpengaruh adalah jarak. Semakin jauh jarak suatu mall dengan lokasi penduduk, maka semakin sedikit pengunjung mall tersebut. 
3. Pada pemodelan yang berdasarkan kategori mall dan tingkat ekonomi penduduk memperlihatkan hasil bahwa untuk setiap kategori mall, pengunjung terbanyak adalah penduduk dengan tingkat ekonomi tinggi (kaya).

4. Pemodelan yang dibuat berdasarkan asumsi bahwa jumlah pengunjung mall yang diperoleh dalam perhitungan adalah jumlah pengunjung mall selama satu bulan (periode bulanan) dengan logika berpikir bahwa seseorang berkunjung ke mall minimal satu kali dalam sebulan untuk memenuhi kebutuhan hidupnya.

5. Hasil akhir perhitungan jumlah pengunjung mall berdasarkan kategori mall memperlihatkan bahwa untuk setiap kategori mall, jumlah pengunjung terbanyak berasal dari penduduk dengan tingkat ekonomi kaya. Oleh karena itu, kami menyarankan untuk dilakukan studi lanjut terkait faktor-faktor yang menjadi penyebab utama penduduk dengan tingkat ekonomi kaya memilih semua jenis kategori mall sebagai tempat berbelanja.

\section{Referensi}

Suthanaya, P. A. (2010). Pemodelan Tarikan Perjalanan Menuju Pusat Perbelanjaan di Kabupaten Badung, Provinsi Bali. Jurnal Ilmiah Teknik Sipil, 14(2).

Gonzalez-Feliu, J., Routhier, J. L., \& Raux, C. (2010). An Attractiveness-Based Model for Shopping Trips in Urban Areas. In 12th World Conference on Transport Research (pp. 1-17).

Marion, Glenn. (2008). An Introduction to Mathematical Modelling. Bioinformatics and Statistics Scotland.

Raharjani, J. (2005). Analisis Faktor-Faktor yang Mempengaruhi Keputusan Pemilihan Pasar Swalayan Sebagai Tempat Berbelanja (Studi Kasus Pada Pasar Swalayan di Kawasan Seputar Simpang Lima Semarang). Jurnal Studi Manajemen dan Organisasi (JSMO), 2(Nomor 1), $1-15$ 